\title{
46.一定照度制御システム
}

\author{
小林俊夫佐藤敬一 \\ （日立照明株式会社）
}

1.はじめに

コンビニエンスストアはライフスタイルの多様化に伴い、24時間営業のウエイトが大きく、又、 他店との競合が激化する中で、夜間と言えども十分な照度の確保が必要となっている。従来の、コ ンビニエンスストア向けの照明制御システムは、昼光利用と夜間の調光制御による照度ダウンで、省 エネを図る方式が採られているが、本報では、十分な照度を確保する中で、省エネを図る方式として、 簡易的一定照度制御システムを開発したので報告する。

\section{2. 制御システムの概要}

照明器具による明るさは、初期の状態から少しづつ暗くなり、設計照度付近で安定する。設計照 度に落ち着く迄の無䭾な明るさをカットし、常に照度を維持することにより、快適性を確保しながら 省エネルギーを行う。従来、一定照度維持としては、照度センサーーにて周囲照度を検出して制御す る方式が採られているが、照度センサー方式では、店内のゴンドラ位置、及びレイアウト変更や飾り 付け等の外的要因の影響を受けて適正な制御が出来なくなる。そこで、図 1 に示す通り、外的要因 で影響されにくい方式として、器具污れ、ランプ光束働程曲線による明るさの点灯時間に対する標準 低減カーブを制御装置内で記憶し、実累積点灯時間に忍じて調光レベルを高くして一定照度維持を行 う。小規模店舖の制御システムに要求される項目としては、簡単施工、簡単調整、簡易オペレーシ ヨン、ローコストがあり、本システムはこれらの考慮して以下の仕様とした。

○本システムの仕様

(1) 制御信号は電灯線搬送方式 (2 線式)

(2) 昼光センサーによる空際照明制御

(3) ランプ点灯時間によりランプ交換お知らせ表示 ランプ付き（2段階表示ランプ）

(4) 点灯時間累積カウント半導体メモリ一内藏 (半永久的記憶)

（5）一定照度モードと節電モード（梁夜調光方式） の切替え可能方式（将来のエネルギ一状況に対応）

(6) 適用 $40 \mathrm{~W}$ - ンプは高効率で低価格のF L 40 を 採用し、さらにF L R 40 タイプも使用可とした。

従来、ランプ交換時期が適切に実施出来なく大幅に照度 低下をしたままの状態で使用されることがあるが、本力式 は、点灯累積時間をカウントしている為、交換準備のお市 すめ表示、さらに時間が経過すると、交換表示ランプ及び、 監視装置へランプ交換信号を出力し、適切な時期の一斉ラ ンプ交換を促す。

3.まとめ

小規模店舖に於ける、簡易省エネの本システムにより、 非制御方式に比べ約 $24 \%$ の省エネ効果が得られる。

Lighting control system for constant illuminance Toshio Kobayashi, Keiichi Sato

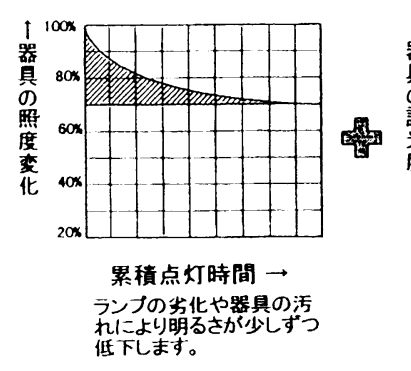

図 1 制御モード

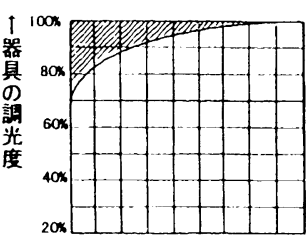

累積点灯時間 $\rightarrow$ 初期に設計照度まで腤光

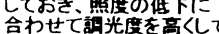
鿖きせて。

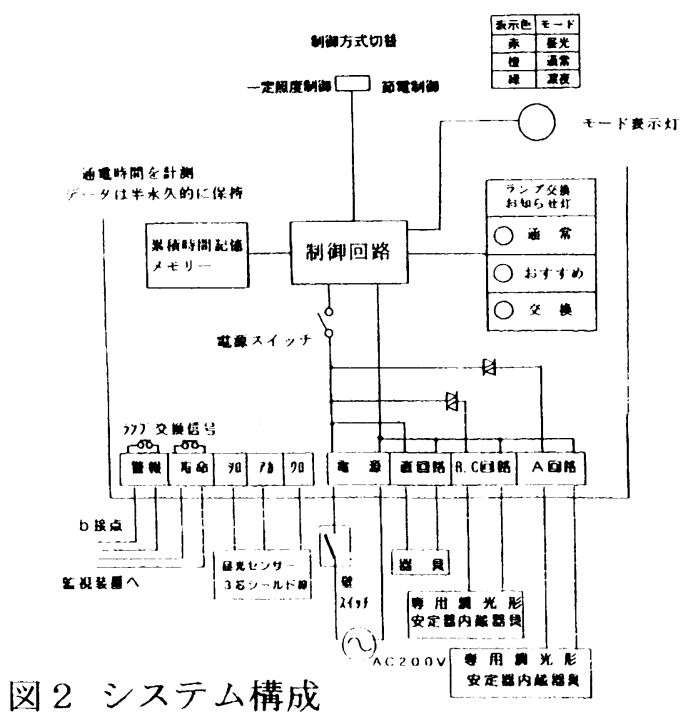

